University of Wollongong

Research Online

Faculty of Engineering and Information

Faculty of Engineering and Information

Sciences - Papers: Part A

Sciences

$1-1-2014$

Support for the integration of green roof constructions within Chinese building Energy Performance Policies

Georgios Kokogiannakis

University of Wollongong, gkg@uow.edu.au

Jo Darkwa

University of Nottingham

Follow this and additional works at: https://ro.uow.edu.au/eispapers

Part of the Engineering Commons, and the Science and Technology Studies Commons

Research Online is the open access institutional repository for the University of Wollongong. For further information contact the UOW Library: research-pubs@uow.edu.au 


\title{
Support for the integration of green roof constructions within Chinese building Energy Performance Policies
}

\author{
Abstract \\ Green roofs could act as a thermal buffer in buildings and offer potential energy savings. However, the \\ energy benefits from green roofs are not usually properly recognised by traditional building energy \\ regulations. Building energy regulations are traditionally over-simplistic during the assessment of the \\ energy performance of complex building constructions. In the case of green roof designs, it is essential \\ that the assessment mechanisms should not ignore the complex heat and moisture balances within the \\ green roof layers. In this paper, dynamic energy modelling that considers the complexity within the green \\ roof layers is adopted to guide policy makers in China on the relationship between using specific \\ thicknesses of roof insulation against green roof layers. Simulations are run for a residential building type \\ by also considering different thermal envelope characteristics across eight large Chinese cities and within \\ the five main climatic zones of China. Results that link the green roof characteristics with respective \\ traditional insulation layers are produced for all cities and it is found that optimising the plant and soil \\ characteristics of green roofs in some climates could substitute more than $125 \mathrm{~mm}$ of roof insulation, \\ while less optimum green roof types could only replace about $25 \mathrm{~mm}$ of roof insulation.
}

\section{Keywords}

building, integration, energy, performance, policies, green, roof, constructions, within, chinese, support

Disciplines

Engineering | Science and Technology Studies

\section{Publication Details}

Kokogiannakis, G. \& Darkwa, J. (2014). Support for the integration of green roof constructions within Chinese building Energy Performance Policies. Energy, 65 71-79. 


\title{
Title:
}

Support for the integration of green roof constructions within Chinese Building Energy Performance Policies

Authors: Georgios Kokogiannakis ${ }^{\mathrm{a}}$, Jo Darkwa ${ }^{\mathrm{a}}$

\begin{abstract}
Affiliation:
${ }^{a}$ Centre for Sustainable Energy Technologies (CSET), The University of Nottingham, 199 Taikang East Rd, Ningbo, 315100 China
\end{abstract}

Corresponding author: Georgios Kokogiannakis

Corresponding email address: georgios.kokogiannakis@ nottingham.edu.cn

Telephone: +86574 88180929

Fax: +86574 88180313

Corresponding postal address: Centre for Sustainable Energy Technologies (CSET), The University of Nottingham, 199 Taikang East Rd, Ningbo, 315100 China 


\section{ABSTRACT}

Green roofs could act as a thermal buffer in buildings and offer potential energy savings. However, the energy benefits from green roofs are not usually properly recognised by traditional building energy regulations. Building energy regulations are traditionally over-simplistic during the assessment of the energy performance of complex building constructions. In the case of green roof designs, it is essential that the assessment mechanisms should not ignore the complex heat and moisture balances within the green roof layers. In this paper, dynamic energy modelling that considers the complexity within the green roof layers is adopted to guide policy makers in China on the relationship between using specific thicknesses of roof insulation against green roof layers. Simulations are run for a residential building type by considering also different thermal envelope characteristics across eight large Chinese cities and within the five main climatic zones of China. Results that link the green roof characteristics with respective traditional insulation layers are produced for all cities and it is found that optimising the plant and soil characteristics of green roofs in some climates could substitute more than $125 \mathrm{~mm}$ of roof insulation, while less optimum green roof types could only replace about $25 \mathrm{~mm}$ of roof insulation.

Keywords: green roofs, dynamic energy modelling, energy regulations, heating and cooling energy savings, insulation levels

\section{INTRODUCTION}

The significant direct and indirect benefits from applying green roofs in buildings have been listed within several publications in the literature, amongst them are for example the green roofs' positive impact on urban heat island mitigation $[1,2]$, storm water management $[3,4]$ and the reduction in some cases of 
the heating and cooling energy requirements in buildings $[5,6]$. Although these benefits are important, the application of green roofs is currently limited and green roofs have been widely applied only in places where policy provides incentives for such roof constructions. However, the potential benefits from green roofs are nowadays being considered by researchers, practitioners and policy makers worldwide. In the case of China where urbanisation is highly evident and living standards inside buildings are improving at a fast rate, green roofs could potentially contribute in reducing outdoor summer temperatures and improve indoor temperatures in a way that heating and cooling energy loads are reduced.

Building energy regulations worldwide and in China have been traditionally based on prescribed requirements for maximum thermal transmittance values (U-values) of each building element and they do not often recognise the benefits of specific low energy saving technologies $[7,8]$. For roof constructions, the U-value targets are usually achieved by installing insulation layers of specific thickness. It is uncommon to notice incentives in building energy regulations that allow flexibility on the method of achieving the levels of thermal insulation without using typical $U$-value calculations and provide therefore the policy mechanisms to recognise the actual energy benefits of green roofs in new buildings. Typical U-value calculations would ignore the additional energy and moisture flow paths in green roofs and the effect of these flow paths on the temperature of the roof's layers. For example U-value calculations do not account for evaporation from the soil and plants, transpiration of the plants, reduced convection in the canopy layer, etc. The only current incentives that directly recognise the energy benefits that could be utilised with the use of green roofs are through voluntary building certification schemes such as LEED [9] and BREEAM [10]. In such schemes, additional certification credits are assigned for buildings that incorporate green roofs and the role of green roofs in reducing energy demand and improving thermal comfort is recognised if evidence is provided through whole building energy simulations. 
In China, building energy regulations have different requirements for the building envelope across five main climatic zones (Figure 1) [11, 12]. Table 1 [11] provides examples of maximum U-values for roof constructions across the five Chinese climates.

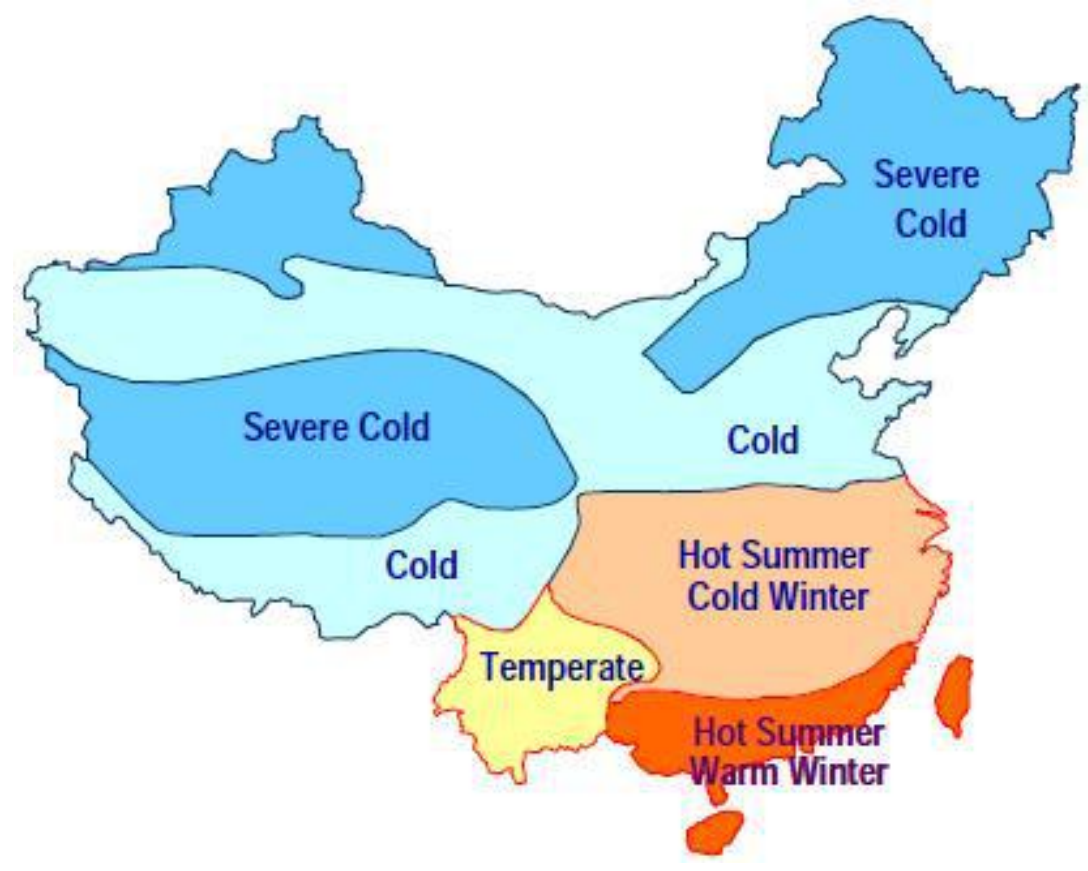

Figure 1 The five main climatic zones of China [11, 12]

Table 1 Examples of maximum roof U-values across the five main Chinese climatic zones [11]

\begin{tabular}{|c|c|c|}
\hline City & Climatic zone & $\begin{array}{c}\text { Maximum U-value for roofs } \\
\left(\mathbf{W} / \mathbf{m}^{2} \mathbf{K}\right)\end{array}$ \\
\hline Harbin & Severe cold & 0.35 \\
\hline Beijing & Cold & 0.55 \\
\hline Shanghai & Hot summer \& Cold winter & 0.7 \\
\hline Kunming & Temperate & 0.89 \\
\hline Hong Kong & Hot summer \& Warm winter & 0.54 \\
\hline
\end{tabular}

The integration of green roofs in building energy regulations should also account for the complexity of such constructions. Green roofs involve complex coupling of heat and moisture balances in the soil and canopy layers and this complexity affects the energy budget of the roof construction overall. It is essential that dynamic modelling should be employed in order to account for the energy and moisture interactions in the green roof layers prior to developing energy regulations that consider the equivalency of green roofs with typical insulated roofs. Developing building regulations involve both 
technical and economic evaluations of the potential regulatory updates. In any case, however, when energy reductions are achieved they should be recognised and rewarded accordingly within the regulations even if the cost for achieving such reductions is not the lowest practically available. Such regulatory updates are already in place in several European countries with minimum whole building energy performance targets that allow several cost-independent options to be adopted in the building design in order to achieve the minimum required energy (or $\mathrm{CO}_{2}$ emissions for example for the case of the UK) targets. Overall, a number of studies in the literature are discussing the cost factor of green roofs $[13,14,15,16]$, however most of these studies investigate specific green roof types for buildings located in specific climates. The general conclusions out of these cost-analysis studies are that green roofs could become an economically feasible construction practice in buildings and, in some cases, have relatively low cost payback periods (11 and 10 years were reported in the literature by [15] and [16] respectively), especially when considering their additional social and environmental benefits.

In this paper, a detailed technical analysis with dynamic energy modelling that considers the complex heat and moisture balances within the green roof layers is adopted to guide policy makers of building energy regulations in China regarding the relationship between using specific thicknesses of roof insulation against different configurations of green roof layers. Since more than $70 \%$ of buildings in China are residential buildings [17] a residential apartment is simulated under different envelope construction types and weather files are used from eight large urbanised Chinese cities that are located within the five main climatic zones of China.

\section{METHODOLOGY}

\subsection{Dynamic simulation tools for green roofs}

The EnergyPlus dynamic whole building simulation program [18] was used for modelling the building cases of this study. The software is currently supported by the U.S. Department of Energy and it 
implements fully the Heat Balance approach [19] in which heat balance equations are solved simultaneously for every calculation time-step and for each of the outside and inside zone surfaces, along with the zone air. The green roof model in EnergyPlus is integrated with the rest of the building model and energy balance calculations are performed for the soil and foliage layers. It accounts for the solar radiation incident on the green roof and it balances the energy gains from the solar radiation with sensible (convection) and latent (evaporation and transpiration) heat flux from soil and plant surfaces combined with conduction of heat into the soil and long-wave thermal radiation to and from the soil and leaf surfaces. A detailed description of the mathematical model is given in the literature [20]. The initial validation effort for the specific green roof model in EnergyPlus has been reported by the developer of the mathematical model [20]. The specific validation study was done for one year and experimental data were used for this purpose. The validation study compared soil surface temperatures and it was reported that the average bias of the simulation was $2.9{ }^{\circ} \mathrm{C}$ and the Root Mean Square Error (RMSE) was $4.1^{\circ} \mathrm{C}[20]$. No comparisons were made in that study for heat fluxes across the roof and the author recognises that the specific validation results included many degress of freedom since measurements were not taken for all the necessary inputs of the simulation. However, improvements on the validation efforts for the specific green roof model have been recently published [21, 22]. In [21] the authors have validated experimentally the green roof model of EnergyPlus and for the different green roof cases of their study they found the RMSE for soil surface temperature to be between $1.5{ }^{\circ} \mathrm{C}$ and $3{ }^{\circ} \mathrm{C}$, while the RMSE for the heat flux transmitted through the green roof cases of the study was between $0.21 \mathrm{~W} / \mathrm{m}^{2}$ to $0.72 \mathrm{~W} / \mathrm{m}^{2}$. On the other hand, the study [21] does not give any details about the inputs for the soil properties and how these inputs correlate with the respective measured soil data. In [22] the authors went through a thorough experimental validation of the green roof model in EnergyPlus and they found the RMSE for soil surface temperature to be between $2.4{ }^{\circ} \mathrm{C}$ and $3.5^{\circ} \mathrm{C}$ for different seasons of the year. 
Building simulation programs have long history of development and there have been excellent descriptions in the literature for the way these programs descritise the built environment and solve the governing equations for the energy and moisture flowpaths in buildings [23, 24]. There has also been significant work done and reported in the literature on the validation of these programs, involving multiyear and multi-team validation projects $[25,26]$. However, in spite these efforts through the long and large validation projects there is still lack of extensive methodological validation for specific capabilities of building simulation programs including the green roof modelling and also other potentially significant modelling advances such as the integrated (i.e. coupled) thermal and air flow modelling, integration of thermal bridges, building integrated renewable energy systems, etc.

EnergyPlus is currently the only whole building simulation program with a green roof model that is available to the users and can model green roofs in such detail while a recent publication reports that the same green roof model has now also been implemented in the TRNSYS program [27]. The specific model in EnergyPlus has some limitations, for example it cannot model time variable plant physical properties (e.g. time variable plant height and leaf growth) but it accounts for detailed moisture and heat exchanges in the green roof and can provide useful conclusions on their energy performance across different climates. The results of this study will therefore be representative for plants that their physical characteristics (height and vegetation density) do not change dramatically over different seasons of the year. The next sections will provide the details of the simulation cases that were used in this study for assessing the energy performance of green roofs in Chinese climates against the performance of typical insulated roofs.

\subsection{Climate and simulated cities}

Annual whole building simulations were undertaken for eight large and important cities in China across the five main climatic zones (Table 2). 
Table 2 Location and climate zones for the 8 Chinese cities

\begin{tabular}{|c|c|c|}
\hline City & $\begin{array}{c}\text { Location: } \\
\text { Latitude \& Longitude }\end{array}$ & Climatic zone \\
\hline Harbin & $45.75^{\circ} \mathrm{N} \& 126.77^{\circ} \mathrm{E}$ & Severe cold \\
\hline Beijing & $39.93^{\circ} \mathrm{N} \& 116.28^{\circ} \mathrm{E}$ & Cold \\
\hline Xian & $34.30^{\circ} \mathrm{N} \& 108.93^{\circ} \mathrm{E}$ & Cold \\
\hline Shanghai & $31.40^{\circ} \mathrm{N} \& 121.47^{\circ} \mathrm{E}$ & Hot summer \& Cold winter \\
\hline Ningbo & $29.52^{\circ} \mathrm{N} \& 121.30^{\circ} \mathrm{E}$ & Hot summer \& Cold winter \\
\hline Kunming & $25.02^{\circ} \mathrm{N} \& 102.68^{\circ} \mathrm{E}$ & Temperate \\
\hline Guangzhou & $23.13^{\circ} \mathrm{N} \& 113.23^{\circ} \mathrm{E}$ & Hot summer \& Warm winter \\
\hline Sanya & $18.23^{\circ} \mathrm{N} \& 109.52^{\circ} \mathrm{E}$ & Hot summer \& Warm winter \\
\hline
\end{tabular}

The simulations for all locations apart from Ningbo use hourly weather data of "Chinese Typical Year Weather (CTYW)" files [28]. These files were developed for use in simulating building heating and air conditioning loads and energy use. There is only one file of climate data for Ningbo that is used locally by building designers. This file has been developed by interpolating values from climate data in Hangzhou and Shanghai. Ambient average monthly temperatures from the different climate files for the cities of the study are given in Table 3.

Table 3 Average monthly temperatures $\left({ }^{\circ} \mathrm{C}\right)$

\begin{tabular}{|c|c|c|c|c|c|c|c|c|c|c|c|c|}
\hline City & Jan & Feb & Mar & Apr & May & Jun & Jul & Aug & Sep & Oct & Nov & Dec \\
\hline Harbin & -18.4 & -13.8 & -3.2 & 7.4 & 14.7 & 19.6 & 21.8 & 21.5 & 13.8 & 5.4 & -4.5 & -13.8 \\
\hline Beijing & -3.4 & 0.1 & 7.1 & 14.7 & 21 & 25.1 & 25.7 & 25.3 & 19.8 & 13.8 & 5.9 & -0.7 \\
\hline Xian & -0.4 & 2.3 & 7.8 & 15 & 19.3 & 24.3 & 25.7 & 25 & 20.1 & 14.3 & 6.7 & 1.6 \\
\hline Shanghai & 4.3 & 5.5 & 8.8 & 14.7 & 19.1 & 24 & 27.7 & 27.7 & 22.9 & 18.5 & 13.5 & 5.7 \\
\hline Ningbo & 4.2 & 5.4 & 8.4 & 14.6 & 19.8 & 24 & 26.8 & 26.5 & 22.2 & 19.2 & 12 & 5.1 \\
\hline Kunming & 8.3 & 10.3 & 14.1 & 16.4 & 19.1 & 20.3 & 20.1 & 19.4 & 18.2 & 15.5 & 11.8 & 7.7 \\
\hline Guangzhou & 13.1 & 14.1 & 17.4 & 22.3 & 25.7 & 27.5 & 29 & 28.5 & 27.5 & 24.4 & 20.4 & 16.1 \\
\hline Sanya & 22.1 & 23.1 & 24.9 & 26.7 & 28.8 & 28.6 & 28.4 & 28.4 & 27.9 & 26.4 & 24 & 21.9 \\
\hline
\end{tabular}

\subsection{Building model and green roof parameters}

A Chinese residential apartment was modelled (Figure 2) and a large number of parameters for the envelope of the building were varied to accommodate the main differences in construction characteristics that are evident across the country's building stock and also to account for future evolution of building energy regulations towards more strictly insulated building envelopes. 


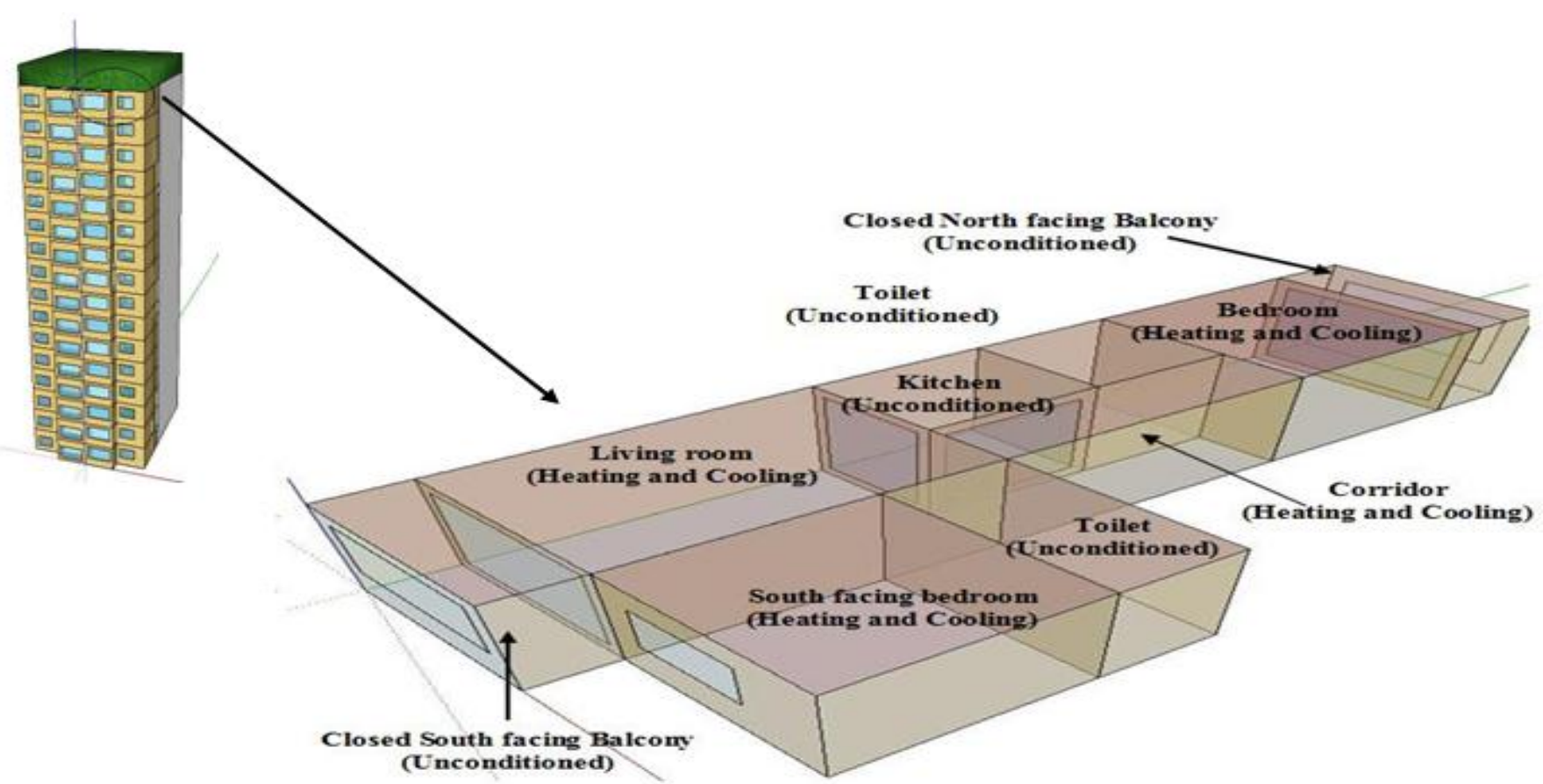

Figure 2: The Chinese apartment used for the modelling cases

Table 4 provides the envelope details that were considered for the different cases of this study. Three levels of external wall insulation were incorporated in the building cases of the study and all cases were combined with two glazing configurations (Table 4).

Table 5 is of particular importance for this study since it lists the roof constructions that were studied with different levels of roof insulation and different types of green roofs. It can been seen in Table 5 (points 1 to 6 ) that the thickness of roof insulation for the simulated cases has been varied from no insulation to up to $125 \mathrm{~mm}$ of insulation in order to reflect the levels of insulation that can be found in older buildings of China and also in new or in potentially future better insulated buildings. The green roof cases that are listed in point 7 of Table 5 were applied and simulated only on top of an uninsulated roof. 36 green roof types were prepared by combining green roof indicative characteristics from the literature such as soil thicknesses [29] and vegetation densities [30] and by adding in half of these green roof types a schedule for a significantly high amount of irrigation, i.e. constant irrigation rate of $0.01 \mathrm{~m}$ per hour, daily from 7.00 to 17.00 o'clock (see Table 5). The amount of irrigation was set considerably high in order to make the green roof fully saturated with water and consequently account in the study 
for the maximum potential amount of evapotranspiration from the roof. Trial simulations for the hot climate of this study (i.e. Sanya) do confirm that cooling load results remain constant for any irrigation values higher than those set in this study. In addition to the above parameters, two variations of the soil's thermal properties are studied based on potential minimum and maximum values for these properties. In practice, soil thermal properties (e.g. thermal conductivity and specific heat capacity) could vary significantly [31] for different types of soil.

\section{Table 4 Construction characteristics for this study}

\begin{tabular}{|c|l|}
\hline $\begin{array}{c}\text { Envelope } \\
\text { elements }\end{array}$ & \multicolumn{1}{c|}{ Parameters } \\
\hline $\begin{array}{c}\text { Three (3) types } \\
\text { of External Walls }\end{array}$ & $\begin{array}{l}\left.\text { 1. Uninsulated concrete wall (thermal transmittance U-value of } 2.8 \mathrm{~W} / \mathrm{m}^{2} \mathrm{~K}\right) \\
\text { 2. Externally medium-insulated concrete wall }\left(25 \mathrm{~mm} \text { of insulation and } \mathrm{U} \text {-value of } 0.83 \mathrm{~W} / \mathrm{m}^{2} \mathrm{~K}\right) \\
\text { 3. Externally heavily-insulated concrete wall }\left(75 \mathrm{~mm} \text { of insulation and } \mathrm{U} \text {-value of } 0.35 \mathrm{~W} / \mathrm{m}^{2} \mathrm{~K}\right) .\end{array}$ \\
\hline $\begin{array}{c}\text { Two (2) types of } \\
\text { External glazing }\end{array}$ & $\begin{array}{l}\left.\text { 1. A single layer clear } 3 \mathrm{~mm} \text { (theoretical U-value of } 5.75 \mathrm{~W} / \mathrm{m}^{2} \mathrm{~K}\right) . \\
\text { 2. A double glazing for which two clear } 3 \mathrm{~mm} \text { layers are separated by an air filled } 13 \mathrm{~mm} \text { gap } \\
\left.\text { (theoretical U-value of } 2.55 \mathrm{~W} / \mathrm{m}^{2} \mathrm{~K}\right) .\end{array}$ \\
\hline
\end{tabular}

\section{Table 5 Roof Construction characteristics for this study}
1. Uninsulated concrete roof (U-value of $2.91 \mathrm{~W} / \mathrm{m}^{2} \mathrm{~K}$ ).
2. Insulated $(25 \mathrm{~mm})$ concrete roof ( $U$ value of $0.85 \mathrm{~W} / \mathrm{m}^{2} \mathrm{~K}$ )
3. Insulated $(50 \mathrm{~mm})$ concrete roof ( $U$ value of $0.5 \mathrm{~W} / \mathrm{m}^{2} \mathrm{~K}$ )
4. Insulated $(75 \mathrm{~mm})$ concrete roof ( $U$ value of $0.35 \mathrm{~W} / \mathrm{m}^{2} \mathrm{~K}$ )
5 . Insulated $(100 \mathrm{~mm})$ concrete roof (U value of $0.27 \mathrm{~W} / \mathrm{m}^{2} \mathrm{~K}$ )
6. Insulated $(125 \mathrm{~mm})$ concrete roof (U value of $0.22 \mathrm{~W} / \mathrm{m}^{2} \mathrm{~K}$ )

(Extruded Polystyrene insulation board with thermal conductivity of $0.03 \mathrm{~W} / \mathrm{mK}$ was assumed in all insulated roofs)

7. All of the following green roof combinations (in total 36 green roof types) were modelled on top of an uninsulated concrete roof:

- Extensive/Semi-intensive/Intensive based on three (3) soil thicknesses: $100 \mathrm{~mm}, 350 \mathrm{~mm}$ and $700 \mathrm{~mm}$.

- Two (2) variations on soil thermal properties:

a) thermal conductivity $0.5 \mathrm{~W} / \mathrm{mK}$, Density $500 \mathrm{~kg} / \mathrm{m}^{3}$, Specific heat $1460 \mathrm{~J} / \mathrm{kgK}$. For the purposes of this paper, this type of soil will be called "Option A";

b) thermal conductivity $1.5 \mathrm{~W} / \mathrm{mK}$, Density $900 \mathrm{~kg} / \mathrm{m}^{3}$, Specific heat $2040 \mathrm{~J} / \mathrm{kgK}$. For the purposes of this paper, this type of soil will be called "Option B". The relationship of the properties between Option A and Option B follows the recommendation in the EnergyPlus source code with regard to the relationship of thermal properties of dry and wet soils.

- Constant over the year Low/Medium/Dense vegetation, defined from the Leaf Area Index (LAI) in the models as $0.1,1$ and 5 respectively.

- One (1) plant evapotranspiration rate that is defined in EnergyPlus by the minimum stomatal resistance input. Green roofs with plants of constant $180 \mathrm{~s} / \mathrm{m}$ minimum stomatal resistance were modelled.

- Non-irrigated and highly irrigated roofs with constant rates of $0.01 \mathrm{~m}$ per hour, daily from 07.00 to 17.00 o'clock. 
All the combinations of the above table were simulated and annual results were extracted for 252 cases per climate (i.e. 2016 annual simulations in total for all eight climates).

The operational characteristics of the building that were assumed for this study are summarised in Tables 6 and 7. In addition, the air flow in the building spaces was assumed to be maintained constant at $0.5 \mathrm{ACH}$ for the bedrooms and $1 \mathrm{ACH}$ for all other building spaces.

Table 6 Assumed building internal heat gains schedules (people and equipment)

\begin{tabular}{|c|c|}
\hline $\begin{array}{c}\text { Weekdays - Bedrooms } \\
\text { 22.00pm to 6.00am: 200 W for each bedroom (occupied) }\end{array}$ & $\begin{array}{c}\text { Weekend - Bedrooms } \\
\text { 22.00pm to 10.00am: 200 W for each bedroom (occupied) }\end{array}$ \\
\hline $\begin{array}{c}\text { Weekdays - Living room } \\
\text { 6.00am to 7.00am and 17.00pm to 22.00pm: } 400 \mathrm{~W} \text { (occupied) }\end{array}$ & $\begin{array}{l}\text { Weekend - Living room } \\
\text { 10.00am to 22.00pm: } 400 \mathrm{~W} \text { (occupied) }\end{array}$ \\
\hline
\end{tabular}

Table 7 Assumed heating and cooling set-points and schedules

\begin{tabular}{|c|c|}
\hline $\begin{array}{l}\text { Weekdays - Bedrooms } \\
\text { 6.00am to } 22.00 \mathrm{pm} \text { : } \\
\text { Setback temperature } 12{ }^{\circ} \mathrm{C} \text { for heating } \\
\text { 22.00pm to } 6.00 \mathrm{am} \text { : } \\
\text { Set-point temperature } 20^{\circ} \mathrm{C} \text { for heating } \\
\text { Set-point temperature } 24^{\circ} \mathrm{C} \text { for cooling }\end{array}$ & $\begin{array}{l}\text { Weekends - Bedrooms } \\
\text { 10.00am to } 22.00 \mathrm{pm} \text { : } \\
\text { Setback temperature } 12^{\circ} \mathrm{C} \text { for heating } \\
\text { 22.00pm to } 10.00 \mathrm{am} \text { : } \\
\text { Set-point temperature } 20^{\circ} \mathrm{C} \text { for heating } \\
\text { Set-point temperature } 24^{\circ} \mathrm{C} \text { for cooling }\end{array}$ \\
\hline $\begin{array}{l}\text { Weekdays - Living room and Corridor } \\
\text { 7.00am to } 17.00 \mathrm{pm} \text { and } 22.00 \mathrm{pm} \text { to } 6.00 \mathrm{am} \text { : } \\
\text { Setback temperature } 12{ }^{\circ} \mathrm{C} \text { for heating }\end{array}$ & $\begin{array}{l}\frac{\text { Weekends - Living room and Corridor }}{22.00 p m \text { to } 10.00 \text { am: }} \\
\text { Setback temperature } 12{ }^{\circ} \mathrm{C} \text { for heating }\end{array}$ \\
\hline $\begin{array}{l}\text { 6.00am to } 7.00 \mathrm{am} \text { and } 17.00 \mathrm{pm} \text { to } 22.00 \mathrm{pm} \text { : } \\
\text { Set-point temperature } 20^{\circ} \mathrm{C} \text { for heating } \\
\text { Set-point temperature } 24{ }^{\circ} \mathrm{C} \text { for cooling }\end{array}$ & $\begin{array}{l}10.00 \mathrm{am} \text { to } 22.00 \mathrm{pm} \text { : } \\
\text { Set-point temperature } 20^{\circ} \mathrm{C} \text { for heating } \\
\text { Set-point temperature } 24{ }^{\circ} \mathrm{C} \text { for cooling }\end{array}$ \\
\hline$\frac{\text { Weekdays - All other zones }}{\text { Unconditioned (no heating \& no cooling) }}$ & $\frac{\text { Weekends - All other zones }}{\text { Unconditioned (no heating \& no cooling) }}$ \\
\hline
\end{tabular}

The comparisons between the simulated cases were made by extracting total annual heating and cooling demands from each case. All roof configurations were compared with each other to determine the most optimum green roof configuration for each climate and the amount of roof insulation that could be replaced by green roofs. EnergyPlus produces CSV files for each simulation of this study and post-processing with macros in MS-Excel was necessary to bring the 2016 simulation results in a format that could be used for the comparisons of this study. 


\section{RESULTS AND DISCUSSION}

A large number of results were extracted and were placed in a database for comparison purposes. It is not possible to present all of the exact outputs from each case and only a small sample of results is therefore given in Table 8. A discussion however, for all the outputs in total will be included in this section.

A general conclusion that could be drawn from Tables 8 and 9 and from the rest of the results in the database is that in cold climates where heating loads could be an issue the intensive green roofs (e.g. soil thickness of $700 \mathrm{~mm}$ ) with soil that has thermal properties as those for "Option A" in Table 5 have better energy performance than the extensive green roofs. It is therefore evident that soil thickness and soil thermal diffusivity properties have the greatest influence on the results for these cold climates because the conduction heat losses and as a result also the convection heat losses are more significant on the roof's energy balance compared with the other energy flow-paths that depend on solar radiation (i.e. solar heat gains through the green roof layers and evaporation). However, the EnergyPlus software does not offer explicit results for a detailed roof surface energy balance and the specific contribution of each energy and moisture flow-path can not be quantified.

\subsection{The example of green roofs in Ningbo}

For Ningbo's climate cases, all of the semi-intensive and intensive green roofs $(350 \mathrm{~mm}$ and $700 \mathrm{~mm}$ of soil thickness respectively) could be equivalent to at least a $25 \mathrm{~mm}$ thick roof insulation. This was confirmed from the simulation results for all the different soil, vegetation and irrigation parameters that were included in this study. In particular, some of the intensive green roofs of this study could also replace nearly up to $75 \mathrm{~mm}$ of roof insulation (see Table 8 ). The green roof configurations that offered the highest energy savings for Ningbo's climate are shown in Table 8 where it can be seen that buildings 
with these types of green roofs had less annual heating and cooling energy requirements than the similar type of buildings that incorporated a $50 \mathrm{~mm}$ thick roof insulation. On the other hand, extensive green roofs which could be a good option for existing buildings since they do not add much additional weight load on building structures can only be equivalent to $25 \mathrm{~mm}$ of roof insulation if the thermal properties of the soil are adjusted to values close to the low conductivity option in Table 5 (i.e. "Option $\left.A^{\prime \prime}\right)$. However, in any case the energy performance of extensive green roofs is much better than the performance of uninsulated roof cases. This comparison against the uninsulated cases can be seen in Table 8 and in Figure 3 where for the climate of Ningbo a reduction of more than $60 \%$ on heating and cooling loads can be noticed when comparing the uninsulated roof cases with the buildings that incorporate green roofs. This is particularly useful to policy makers who could use databases such as the one developed for this study in order to incorporate properly green roofs within building energy regulations for new and existing buildings. 
Table 8 Sample of results for the climate of Ningbo

\begin{tabular}{|c|c|c|c|c|c|c|c|}
\hline \multicolumn{8}{|c|}{ Building parameters: Double glazing windows \& Medium-insulated wall (as defined in Table 4) } \\
\hline & \multicolumn{4}{|c|}{ Green roof parameters } & \multicolumn{3}{|c|}{ Results } \\
\hline $\begin{array}{c}\text { Roof } \\
\text { insulation }\end{array}$ & LAI & $\begin{array}{c}\text { Soil } \\
\text { thickness } \\
(\mathbf{m m}) \\
\end{array}$ & $\begin{array}{l}\text { Soil thermal } \\
\text { properties }\end{array}$ & Irrigation & $\begin{array}{c}\text { Annual } \\
\text { Heating } \\
(\mathbf{k W h}) \\
\end{array}$ & $\begin{array}{c}\text { Annual } \\
\text { Cooling } \\
(\mathbf{k W h}) \\
\end{array}$ & $\begin{array}{c}\text { Total } \\
\text { Heating + Cooling } \\
(\mathrm{kWh}) \\
\end{array}$ \\
\hline $0 \mathrm{~mm}$ & - & - & - & - & 5426 & 741 & 6167 \\
\hline $25 \mathrm{~mm}$ & - & - & - & - & 1673 & 844 & 2517 \\
\hline $50 \mathrm{~mm}$ & - & - & - & - & 1320 & 871 & 2191 \\
\hline $75 \mathrm{~mm}$ & - & - & - & - & 1181 & 884 & 2065 \\
\hline $100 \mathrm{~mm}$ & - & - & - & - & 1107 & 892 & 1999 \\
\hline $125 \mathrm{~mm}$ & - & - & - & - & 1062 & 897 & 1959 \\
\hline & & & & & & & Best configurations: \\
\hline $\begin{array}{c}0 \mathrm{~mm} \\
\text { (Green roof) }\end{array}$ & 0.1 & 700 & $\begin{array}{l}\lambda=0.5 \mathrm{~W} / \mathrm{mK} \\
\mathrm{C}=1460 \mathrm{~J} / \mathrm{kgK} \\
\rho=500 \mathrm{~kg} / \mathrm{m}^{3}\end{array}$ & YES & 1176 & 915 & $\begin{array}{c}2091 \text { (2107 with NO } \\
\text { irrigation) }\end{array}$ \\
\hline $\begin{array}{c}0 \mathrm{~mm} \\
\text { (Green roof) }\end{array}$ & 1 & 700 & $\begin{array}{l}\lambda=0.5 \mathrm{~W} / \mathrm{mK} \\
\mathrm{C}=1460 \mathrm{~J} / \mathrm{kgK} \\
\rho=500 \mathrm{~kg} / \mathrm{m}^{3}\end{array}$ & YES & 1179 & 913 & $\begin{array}{c}2092 \text { (2121 with NO } \\
\text { irrigation) }\end{array}$ \\
\hline $\begin{array}{c}0 \mathrm{~mm} \\
\text { (Green roof) }\end{array}$ & 5 & 700 & $\begin{array}{l}\lambda=0.5 \mathrm{~W} / \mathrm{mK} \\
\mathrm{C}=1460 \mathrm{~J} / \mathrm{kgK} \\
\rho=500 \mathrm{~kg} / \mathrm{m}^{3}\end{array}$ & YES & 1193 & 898 & $\begin{array}{c}\text { 2091(2101 with NO } \\
\text { irrigation) }\end{array}$ \\
\hline & & & & & & & Worse configurations: \\
\hline $\begin{array}{c}0 \mathrm{~mm} \\
\text { (Green roof) }\end{array}$ & 1 & 100 & $\begin{array}{l}\lambda=1.5 \mathrm{~W} / \mathrm{mK} \\
\mathrm{C}=2040 \mathrm{~J} / \mathrm{kgK} \\
\rho=900 \mathrm{~kg} / \mathrm{m}^{3}\end{array}$ & NO & 1504 & 1125 & $\begin{array}{c}2629(2579 \text { with } \\
\text { irrigation })\end{array}$ \\
\hline $\begin{array}{c}0 \mathrm{~mm} \\
\text { (Green roof) }\end{array}$ & 0.1 & 100 & $\begin{array}{l}\lambda=1.5 \mathrm{~W} / \mathrm{mK} \\
\mathrm{C}=2040 \mathrm{~J} / \mathrm{kgK} \\
\rho=900 \mathrm{~kg} / \mathrm{m}^{3}\end{array}$ & NO & 1489 & 1121 & 2610 \\
\hline $\begin{array}{c}0 \mathrm{~mm} \\
\text { (Green roof) }\end{array}$ & 0.1 & 100 & $\begin{array}{l}\lambda=1.5 \mathrm{~W} / \mathrm{mK} \\
\mathrm{C}=2040 \mathrm{~J} / \mathrm{kgK} \\
\rho=900 \mathrm{~kg} / \mathrm{m}^{3}\end{array}$ & YES & 1664 & 917 & 2581 \\
\hline
\end{tabular}

\subsection{Green roofs energy performance for different Chinese cities}

The results revealed that green roofs could offer energy benefits in all climates. The coldest and the hottest climates of this study will be briefly discussed below and the outcomes from the simulations of all climates are summarised in Table 9 and Figure 3. Figure 3 also summarises the resulted energy performance of the best and worst performing green roofs after being applied on top of uninsulated roofs and a comparison is also made between these green roof cases in Figure 3 and the equivalent in terms of energy performance traditionally insulated roofs. 
Table 9 Relationship between green roofs and roof insulation thickness

\begin{tabular}{|c|c|c|c|}
\hline \multirow[b]{2}{*}{ City } & \multicolumn{3}{|c|}{ Roof insulation thickness that could be replaced } \\
\hline & by the green roof that offered the greatest energy savings & $\begin{array}{l}\text { by all intensive } \\
\text { cases }(700 \mathrm{~mm} \text { soil } \\
\text { thickness) }\end{array}$ & $\begin{array}{l}\text { by all extensive } \\
\text { cases }(100 \mathrm{~mm} \text { soil } \\
\text { thickness })\end{array}$ \\
\hline Ningbo & $\begin{array}{l}\text { Greater than } 50 \mathrm{~mm} \text { and less than } 75 \mathrm{~mm} \\
\text { Green roof details: } \\
\text { soil thickness }=700 \mathrm{~mm}, \lambda=0.5 \mathrm{~W} / \mathrm{mK}, \mathrm{C}=1460 \mathrm{~J} / \mathrm{kgK}, \rho=500 \mathrm{~kg} / \mathrm{m}^{3} \text {, } \\
\text { LAI }=5 \text {, Irrigated }\end{array}$ & $\begin{array}{l}\text { Greater than } 25 \mathrm{~mm} \\
\text { and less than } 50 \mathrm{~mm}\end{array}$ & $\begin{array}{l}\text { Greater than } 0 \mathrm{~mm} \\
\text { and less than } 25 \mathrm{~mm}\end{array}$ \\
\hline Harbin & $\begin{array}{l}\text { Greater than } 75 \mathrm{~mm} \text { and less than } 100 \mathrm{~mm} \\
\text { Green roof details: } \\
\text { soil thickness }=700 \mathrm{~mm}, \lambda=0.5 \mathrm{~W} / \mathrm{mK}, C=1460 \mathrm{~J} / \mathrm{kgK}, \rho=500 \mathrm{~kg} / \mathrm{m}^{3} \text {, } \\
\text { LAI }=0.1 \text {, Irrigated (Irrigation is not an important parameter) }\end{array}$ & $\begin{array}{l}\text { Greater than } 25 \mathrm{~mm} \\
\text { and less than } 50 \mathrm{~mm}\end{array}$ & $\begin{array}{l}\text { Greater than } 25 \mathrm{~mm} \\
\text { and less than } 50 \mathrm{~mm}\end{array}$ \\
\hline Beijing & $\begin{array}{l}\text { Greater than } 100 \mathrm{~mm} \text { and less than } 125 \mathrm{~mm} \\
\text { Green roof details: } \\
\text { soil thickness }=700 \mathrm{~mm}, \lambda=0.5 \mathrm{~W} / \mathrm{mK}, \mathrm{C}=1460 \mathrm{~J} / \mathrm{kgK}, \rho=500 \mathrm{~kg} / \mathrm{m}^{3} \text {, } \\
\mathrm{LAI}=0.1 \text {, Irrigated (if non-irrigated then roofs with LAI }=5 \text { offer higher } \\
\text { energy savings than those with LAI }=0.1 \text { ) }\end{array}$ & $\begin{array}{l}\text { Greater than } 25 \mathrm{~mm} \\
\text { and less than } 50 \mathrm{~mm}\end{array}$ & $\begin{array}{l}\text { Greater than } 0 \mathrm{~mm} \\
\text { and less than } 25 \mathrm{~mm}\end{array}$ \\
\hline Xian & $\begin{array}{l}\text { Greater than } 100 \mathrm{~mm} \text { and less than } 125 \mathrm{~mm} \\
\text { Green roof details: } \\
\text { soil thickness }=700 \mathrm{~mm}, \lambda=0.5 \mathrm{~W} / \mathrm{mK}, \mathrm{C}=1460 \mathrm{~J} / \mathrm{kgK}, \rho=500 \mathrm{~kg} / \mathrm{m}^{3} \text {, } \\
\text { LAI }=5 \text { (LAI is not an important parameter), Irrigated }\end{array}$ & $\begin{array}{l}\text { Greater than } 25 \mathrm{~mm} \\
\text { and less than } 50 \mathrm{~mm}\end{array}$ & $\begin{array}{l}\text { Greater than } 0 \mathrm{~mm} \\
\text { and less than } 25 \mathrm{~mm}\end{array}$ \\
\hline Shanghai & $\begin{array}{l}\text { Greater than } 100 \mathrm{~mm} \text { and less than } 125 \mathrm{~mm} \\
\text { Green roof details: } \\
\text { soil thickness }=700 \mathrm{~mm}, \lambda=0.5 \mathrm{~W} / \mathrm{mK}, C=1460 \mathrm{~J} / \mathrm{kgK}, \rho=500 \mathrm{~kg} / \mathrm{m}^{3} \text {, } \\
\text { LAI }=5 \text {, Irrigated }\end{array}$ & $\begin{array}{l}\text { Greater than } 25 \mathrm{~mm} \\
\text { and less than } 50 \mathrm{~mm}\end{array}$ & $\begin{array}{l}\text { Greater than } 0 \mathrm{~mm} \\
\text { and less than } 25 \mathrm{~mm}\end{array}$ \\
\hline Kunming & $\begin{array}{l}\text { Greater than } 125 \mathrm{~mm} \\
\text { Green roof details: } \\
\text { A large number of green roofs performed better than } 125 \mathrm{~mm} \text { of roof } \\
\text { insulation and precise conclusions could not be drawn for the best type of } \\
\text { green roof in this temperate climate. The highest amount of energy } \\
\text { savings overall for this climate was given by intensive green roofs, i.e. } \\
\text { thickness of soil was the most dominant factor for achieving the } \\
\text { maximum possible energy savings from green roofs. }\end{array}$ & $\begin{array}{l}\text { Greater than } 0 \mathrm{~mm} \\
\text { and less than } 25 \mathrm{~mm} \\
\text { (mostly close to } \\
25 \mathrm{~mm} \text { ) }\end{array}$ & $\begin{array}{l}\text { Greater than } 0 \mathrm{~mm} \\
\text { and less than } 25 \mathrm{~mm}\end{array}$ \\
\hline Guangzhou & $\begin{array}{l}\text { Greater than } 125 \mathrm{~mm} \\
\text { Green roof details: } \\
\text { soil thickness }=700 \mathrm{~mm}, \lambda=1.5 \mathrm{~W} / \mathrm{mK}, C=2040 \mathrm{~J} / \mathrm{kgK}, \rho=900 \mathrm{~kg} / \mathrm{m}^{3} \text {, } \\
\text { LAI }=5 \text {, Irrigated (results are mostly affected by the irrigation) }\end{array}$ & $\begin{array}{l}\text { Greater than } 0 \mathrm{~mm} \\
\text { and less than } 25 \mathrm{~mm}\end{array}$ & $\begin{array}{l}\text { Greater than } 0 \mathrm{~mm} \\
\text { and less than } 25 \mathrm{~mm}\end{array}$ \\
\hline Sanya & $\begin{array}{l}\text { Greater than } 125 \mathrm{~mm} \\
\text { Green roof details: } \\
\text { soil thickness }=100 \mathrm{~mm}, \lambda=1.5 \mathrm{~W} / \mathrm{mK}, C=2040 \mathrm{~J} / \mathrm{kgK}, \rho=900 \mathrm{~kg} / \mathrm{m}^{3} \text {, } \\
\text { LAI }=5 \text {, Irrigated }\end{array}$ & $\begin{array}{l}\text { Greater than } 0 \mathrm{~mm} \\
\text { and less than } 25 \mathrm{~mm}\end{array}$ & $\begin{array}{l}\text { Greater than } 0 \mathrm{~mm} \\
\text { and less than } 25 \mathrm{~mm}\end{array}$ \\
\hline
\end{tabular}




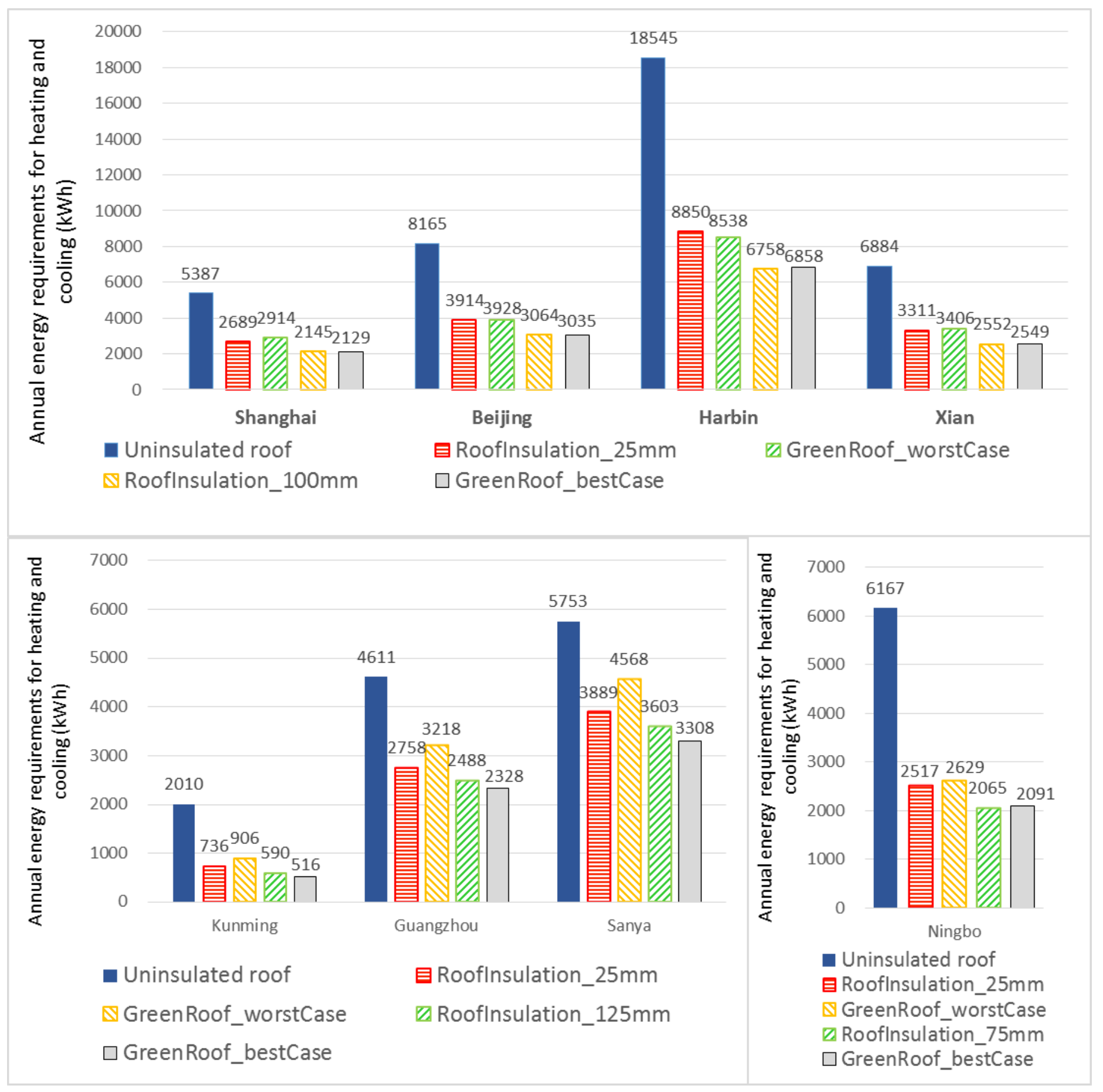

Figure 3: Summary of results for the uninsulated roof cases, the best and worst performing green roofs of this study and their equivalent (of the best/worst green roof cases) traditionally insulated roofs.

Harbin is the coldest city from those included in this paper and one of the coldest cities in China. Heating load is the dominating load and the results show that green roofs in this climate offer more energy savings and could replace slightly thicker layers of roof insulation compared with the cases of Ningbo's 
climate. Intensive green roofs for such a cold climate could substitute up to $75 \mathrm{~mm}$ of roof insulation if soil with thermal properties as those for "Option A" in Table 5 is used. In Harbin's climate, all types of green roofs could be equivalent to a minimum of $25 \mathrm{~mm}$ of roof insulation for all the types of building and green roof parameters that were included in this study.

Sanya is the Chinese city of this study that has the warmest climate. It can be confirmed from the simulation results that there is no heating load for the building cases of this climate. It was found that the characteristics of green roofs are very important in determining their energy performance for such a warm climate. For example, an intensive highly irrigated green roof that incorporates soil of thermal properties as those for "Option $A$ " in Table 5 and dense vegetation (LAI=5) could easily replace more than $125 \mathrm{~mm}$ of roof insulation and reduce significantly the cooling loads of buildings in such climate. However, if the characteristics of the intensive green roofs are not optimised the roof insulation that could be replaced by such roofs in such hot climate is less than $25 \mathrm{~mm}$. This is also true for extensive green roofs that are installed on the buildings of this climate. Vegetation density and irrigation are therefore the most important green roof energy-related parameters for this hot climate. This is a reasonable conclusion because a densely vegetated roof could limit the significant for this climate solar heat gains through the roof and could have high evaporation rates from the plants. Irrigation does also increase the evaporation rates from the plants and the soil, and it therefore reduces the high cooling requirements of the building in such hot climates. Such conclusions from the results would not be possible to be drawn and demonstrated with a simplified assessment tool that does not account for processes such as for evaporation, solar radiation exchanges to and from the plant canopy layer, etc.

The soil thermal properties are obviously not affecting the energy performance of extensive green roofs in Sanya as much as for the intensive roofs. It is interesting to note at this point that an extensive green roof with soil that has thermal properties as those for "Option B" in Table 5 gave the highest reductions of cooling energy requirements in Sanya (see Table 9). However, the differences in the results between 
the respective extensive and intensive green roofs (i.e. between green roofs that have only different soil thickness with each other) were insignificant in this type of climate.

Table 9 provides guidance about the energy performance of green roofs in relation to roof insulation layers. This offers a simple way to allow the inclusion of green roofs within the Chinese building energy regulations across the wide variety of Chinese climates. Table 9 will also be the basis of the discussion in the next section 3.3.

\subsection{Sensitivity of results to green roof parameters}

The simulation results database could also be used to identify the most significant parameters that are affecting the energy performance of green roofs across different climates.

It has been already mentioned in this paper and also highlighted from Table 9 that some types of extensive green roofs in hot climates perform better or the same as the respective intensive green roofs. In such hot climates irrigating the roof increases the water content of the soil and can offer large cooling load reductions. However, the energy savings that could be obtained by these irrigated green roof cases should be further assessed by taking into account the cost of water that is needed on the roofs. Existing studies however do not consider the water cost as a significant figure in economic evaluations of green roofs. For example Chan and Chow [16] report that in Hong Kong the cost of water is relatively low compared with the cost of electricity and it could be therefore ignored in an economic evaluation study. In other studies [32] the water cost has also been found to be small, in particular for extensive green roofs [33]. In any case, sustainable water use practices should be recommended for example by collecting and reusing rain water and the run-off water from the green roof's drainage layer. Some examples of such sustainable water use practices can be found in the literature [34] where it is demonstrated that green roofs could also be used as an effective water conservation technique. 
For non-irrigated intensive green roofs in the hot climates of the study, soil with thermal properties of "Option A" in Table 5 offer more energy savings than the soil of "Option B", however the opposite is true for irrigated intensive green roofs. The density of vegetation on the roof is also important for such hot climates. The results show that highly dense plants (e.g. LAl $=5$ ) could reduce cooling loads in all types of green roofs that were simulated in this study compared with the low vegetation density (e.g. $\mathrm{LAI}=0.1$ ) roofs.

On the other hand, in cold climates with high heating loads the intensive green roofs do offer considerably more energy savings than the respective extensive green roofs. Irrigation and vegetation density are not important parameters for the energy performance of intensive green roofs in such cold climates. However, the thermal properties of the soil should be optimised towards values as those used for "Option A" (Table 5) in this paper or towards soils with as low thermal conductivity as possible. While extensive green roofs do not offer as much energy savings as intensive green roofs in climates with high heating loads they can still offer considerable energy savings compared with the uninsulated roofs. The thermal properties of the soil are also the most important parameter for extensive green roofs in such cold climates, i.e. soils with values similar or better than those for "Option A" in Table 5 are the preferred option.

The mild climate of Kunming was challenging in terms of identifying the most optimum green roof parameters that could provide higher energy savings for heating and cooling loads. The results show that both intensive and extensive green roofs were beneficial in such climate. In such mild climate, there were not large differences between the energy savings offered from the intensive green roofs and the energy savings offered by the respective type of extensive green roof that was configured with the same plant, irrigation and soil thermal properties characteristics as the intensive green roofs. For both intensive and extensive green roofs, the green roof configuration that offered less reductions on annual 
heating and cooling loads in such climate was the one that incorporated non-dense vegetation layers $(L A I=0.1)$, soil with thermal properties as those for "Option B" in Table 5 and no irrigation.

Finally, it can be noticed from the results analysis that there were some differences between the best energy performing green roof cases of Ningbo and Shanghai climates. The two cities are generally close to each other and the climates are expected to be similar in reality. However, the results from the simulations have shown that the best green roof configuration in Shanghai is equivalent to a roof insulation layer that is between $100 \mathrm{~mm}$ to $125 \mathrm{~mm}$ while the best green roof configuration in Ningbo could only be equivalent to a roof insulation layer that is less than $75 \mathrm{~mm}$ (see Table 9). The building models were the same for both Shanghai and Ningbo simulations, which means that differences in the climate files were the reasons for the different performance of green roofs in these two locations. There is a lack for standardised climate files that could provide the inputs for energy simulation programs for some Chinese cities and the climate file for Ningbo is only one that practitioners use locally. The results for the annual heating and cooling loads could be used here in order to provide a generic explanation for the different performance of green roofs in these two climates. It can be seen that the simulations for Ningbo gave higher annual heating requirements than cooling requirements (e.g. for the best energy performing case: $1193 \mathrm{kWh}$ per year for heating and $898 \mathrm{kWh}$ per year for cooling respectively) while for Shanghai the annual heating energy requirements were less than the annual cooling energy requirements (e.g. for the same best energy performing case as for Ningbo: $897 \mathrm{kWh}$ per year for heating and $1232 \mathrm{kWh}$ per year for cooling respectively). These results show that the dominating load is the cooling load for Shanghai's climate cases and the heating load for Ningbo's climate cases. Green roofs could replace thicker insulation layers in the hot climates of this study where cooling loads are the main thermal loads of buildings (e.g. Sanya and Guangzhou), which explains why the results were more favourable for the performance of green roofs with the use of Shanghai's climate file than with the use of Ningbo's climate file. 


\section{CONCLUSIONS}

Detailed whole building simulation was used in this study to appraise the thermal performance of green roofs and provide guidance to policy makers on how to better integrate such technologies within building energy regulations in China. It was found that all types of green roofs could reduce heating and cooling loads when compared with traditional uninsulated roofs.

In cold climates and other locations with notable heating seasons (i.e. Xian, Shanghai and Ningbo), all types of intensive green roofs were equivalent to at least $25 \mathrm{~mm}$ of roof insulation. Configuring the properties of green roofs in an optimum way for such climates could be more beneficial than a $100 \mathrm{~mm}$ roof insulation layer. The density of vegetation is not an important property for green roofs in these climates but the soil thickness and the thermal properties of the soil should be optimised to achieve the highest heating and cooling load reductions.

Green roofs could also be beneficial in mild and hot climates but the simulation results have shown to be sensitive on the configuration of the green roof characteristics. The most optimum in terms of energy performance green roof configurations in this type of climates could replace more than $125 \mathrm{~mm}$ of roof insulation, while the less optimum could replace less than $25 \mathrm{~mm}$ of roof insulation. In such hot climates, if extensive green roofs are irrigated and are incorporating dense vegetation layers they could offer more reductions in heating and cooling loads of the buildings than intensive green roofs.

China is a large country with a variety of different climates and dense urban environments. Assessing the energy performance of green roofs across all climates with detailed simulation techniques is essential for utilising the maximum possible energy savings that such roofs could offer. Results databases such as the one developed for this study could be used to develop policies for a wider spread of these energy saving constructions in practice. However, the detailed modelling techniques of green roofs could also be further developed to overcome some of the existing limitations and this study could 
be further expanded by simulating more building types and additional heating and cooling control systems. Whole building simulation programs could prove to be a necessary tool for better integrating future complex energy saving measures (e.g. green roofs) within traditional building regulations.

Additional complex issues that were outside the scope of this paper may arise in practice for the implementation of green roofs in China and further research is needed to overcome potential cost issues between building developers and building owners, in particular for the North part of China where heating is supplied via district heating and billing is based on the basis of floor area instead of the actual measured energy consumption.

\section{ACKNOWLEDGEMENT}

The authors would like to thank Ningbo Science \& Technology Bureau for funding the research of this study as part of a Soft Science project (Grant No. 2011A1051) and the National Natural Science Foundation of China (NSFC) to also support this study (Grant No. 51208271).

\section{REFERENCES}

[1] Alexandri E, Jones P. Temperature decreases in an urban canyon due to green walls and green roofs in diverse climates. Building and Environment 2008;43:480-93.

[2] Susca T, Gaffin SR, Dell'Osso GR. Positive effects of vegetation: Urban heat island and green roofs. Environmental Pollution 2011;159:2119-26.[3] Mentens J, Raes D, Hermy M. Green roofs as a tool for solving the rainwater runoff problem in the urbanized 21st century? Landscape and Urban Planning 2006;77:217-26.[4] Teemusk A, Mander U. Rainwater runoff quantity and quality performance from a green roof: the effects of short-term events. Ecological Engineering 2007;30:27177. [5] Wong NH, Chen Y, Ong CL, Sia A. Investigation of thermal benefits of rooftop garden in the tropical environment. Building and Environment 2003;38:261-70.[6] Palomo DBE. Analysis of the green roofs cooling potential in buildings. Energy and Buildings 1998;27:179-93.[7] Murphy G, Kummert M, Anderson B, Counsell J. A comparison of the UK Standard Assessment Procedure (SAP) and detailed simulation of building-integrated renewable energy systems. Proceedings International Building Performance Simulation Association (IBPSA) conference '09, University of Strathclyde, Glasgow, UK. 2009;1177-84.[8] DCLG. Building Regulations Energy efficiency requirements for new dwellings - A forward look at what standards may be in 2010 and 2013. Department for Communities and Local Government, London, UK. 2007. [9] LEED. Whole building certification. U.S. Green Building Council. USA. Available from: www.usgbc.org/LEED/ (Last accessed on: 26 March 2013).

[10] BREEAM. Environmental assessment method for buildings. BRE, UK. Available from: http://www.breeam.org/ (Last accessed on: 26 March 2013).

[11] IEA (International Energy Agency). Energy efficiency requirements in Building Codes, energy efficiency policies for new buildings. IEA Information Paper, Paris, France. 2008. Available from:

http://www.iea.org/publications/freepublications/publication/name,3780,en.html (Last accessed on: 2 July 2013).

[12] Lam JC, Wan KKW, Tsang CL, Yang L. Building energy efficiency in different climates. Energy Conversion and Management 2008;49:2354-66. 
[13] Carter T, Keeler A. Development and application of a building energy performance metric for green roof systems. Journal of Environmental Management 2008;87:350-64.

[14] Lee A. Life cycle cost analysis-green roofs form an investment. Proceedings of the Second North American Green Roof Conference: Greening Rooftops for Sustainable Communities, Portland, OR, The Cardinal Group, Toronto. 2004.

[15] Clark C, Adrians P, Talbot B. Probabilistic economic analysis of green roof benefits for policy design. Proceedings of the Fourth North American Green Roof Conference: Greening Rooftops for Sustainable Communities, Boston, MA, The Cardinal Group, Toronto. 2006.

[16] Chan ALS, Chow TT. Energy and economic performance of green roof system under future climatic conditions in Hong Kong, Energy and Buildings, 2013;64:182-98.

[17] Lang S. Progress in energy-efficiency standards for residential buildings in China, Energy and Buildings, 2004;36:1191-96.

[18] EnergyPlus 7.2. Building energy simulation program. US Department of Energy, USA, 2010. Available from: http://www.energyplus.gov (Last accessed on: 4 April 2013).

[19] ASHRAE (American Society of Heating, Refrigerating and Air-Conditioning Engineers). 2005 ASHRAE Handbook Fundamentals (SI), chapter 30. Atlanta, USA. 2005.

[20] Sailor DJ. A green roof model for building energy simulation programs. Energy and Buildings 2008;40:1466-78.

[21] Chan ALS, Chow TT. Evaluation of Overall Thermal Transfer Value (OTTV) for commercial buildings constructed with green roof, Applied Energy 2013;107:10-24.

[22] Moody SS, Sailor DJ. Development and application of a building energy performance metric for green roof systems. Energy and Buildings 2013;60:262-69.

[23] Clarke JA. Energy simulation in building design (2 ${ }^{\text {nd }}$ Edition). Butterworth-Heinemann. ISBN 0-750-65082-6. Oxford, UK. 2001.

[24] EnergyPlus 8.0.0. EnergyPlus engineering reference - The reference to EnergyPlus calculations. US Department of Energy, USA. 2013. Available from: http://apps1.eere.energy.gov/buildings/energyplus/pdfs/engineeringreference.pdf (Last accessed on: 3 September 2013).

[25] Jensen SO (editor). Validation of Building Energy Simulation Programs, part I and II. Research Report of the Subgroup Model Validation and Development; the PASSYS Project. Commission of the European Communities, DGXII. 1994.

[26] Strachan PA, Kokogiannakis G, Macdonald IA. History and development of validation with the ESP-r simulation program. Building and Environment 2008; 43:601-9.

[27] Jaffal I, Ouldboukhitine S-E, Belarbi R. A comprehensive study of the impact of green roofs on building energy performance. Renewable Energy 2012;43:157-64.

[28] Qingyuan Z, Huang J. Chinese Typical Year Weather Data for Architectural Use (in Chinese). ISBN 7-111-14810-X. Beijing: China Machine Press; 2004.

[29] Berndtsson JC. Green roof performance towards management of runoff water quantity and quality: A review. Ecological Engineering 2010;36:351-60.

[30] Dickinson RE, Henderson-Sellars A, Kennedy PJ, Wilson MF. Biosphere-Atmosphere Transfer Scheme (BATS) for the NCAR Community Climate Model. Atmospheric Analysis and Prediction Division of National Center for Atmospheric Research, Boulder, Colorado, NCAR/TN-275 +STR, 1986.

[31] Darkwa J, Suba G, Kokogiannakis G. An investigation into the thermophysical properties and energy dynamics of an intensive green roof. JP Journal of Heat and Mass Transfer. 2013;7:65-84.

[32] Peri G, Traversoa M, Finkbeiner M, Rizzo G. The cost of green roofs disposal in a life cycle perspective: Covering the gap. Energy. 2012;48:406-14.

[33] Niu H, Clark C, Zhou J, Adriaens P. Scaling of Economic Benefits from Green Roof Implementation in Washington, DC. Environmental Science \& Technology. 2010;44:4302-08.

[34] Chang N-B, Rivera BJ, Wanielista MP. Optimal design for water conservation and energy savings using green roofs in a green building under mixed uncertainties. Journal of Cleaner Production. 2011;19:1180-88. 